\title{
Mycoplasma imitans sp. nov. Is Related to Mycoplasma gallisepticum and Found in Birds
}

\author{
JANET M. BRADBURY, ${ }^{1 *}$ OSAMA M. SAED ABDUL-WAHAB, ${ }^{1}$ CHRISTINE A. YAVARI, ${ }^{1}$ \\ JEAN-PAUL DUPIELLET, ${ }^{2}$ AND JOSY M. BOVÉ ${ }^{2}$ \\ Department of Veterinary Pathology, University of Liverpool, Leahurst, Neston, South Wirral L64 7TE, \\ United Kingdom, ${ }^{1}$ and Laboratoire de Biologie Cellulaire et Moleculaire, Institut National de \\ la Recherche Agronomique et Université de Bordeaux II, Domaine de la \\ Grand Ferrade, 33883 Villenave d'Ornon, Cedex, France ${ }^{2}$
}

\begin{abstract}
A mycoplasma designated strain $4^{229^{T}}(T=$ type strain) was isolated in 1984 from the turbinate of a duck in France, and similar strains were isolated from geese in France and from a partridge in England. All of these strains were originally identified as Mycoplasma gallisepticum by immunofluorescence and growth inhibition tests, but subsequent serological and molecular studies indicated only a partial relationship to this species and DNA-DNA hybridization studies revealed only approximately 40 to $46 \%$ genetic homology with $M$. gallisepticum PG31 ${ }^{\mathrm{T}}$. In this study morphological, cultural, and physical investigations were carried out on strain $4229^{\mathrm{T}}$ and partridge strain B2/85, after we first demonstrated the similarity between these organisms by performing a restriction enzyme analysis of their DNAs. Both strains had phenotypic properties very similar to $M$. gallisepticum properties, including the presence of an attachment organelle. As a result of these investigations, the organisms were assigned to the class Mollicutes, the order Mycoplasmatales, and the genus Mycoplasma. They fermented glucose, reduced triphenyl tetrazolium chloride aerobically and anaerobically, and exhibited hemadsorption and hemagglutination, but other biochemical tests were negative. Apart from a serological cross-reaction with $M$. gallisepticum, these organisms exhibited no significant relationship with any previously described Mycoplasma species as determined by growth inhibition or immunofluorescence tests or with a number of additional serovars and unclassified avian strains. This Mycoplasma taxon therefore appears to be a new species, for which we propose the name Mycoplasma imitans. The type strain is strain 4229 (= NCTC 11733 = ATCC 51306). The significance of the organism has not been fully investigated, but preliminary in vitro and in vivo studies have indicated that it may be pathogenic.
\end{abstract}

Mycoplasma gallisepticum is a well-known respiratory pathogen of chickens and turkeys, and there have been occasional reports of isolation of this organism from other avian species, such as ducks $(4,27)$, geese $(5)$, pheasants $(32$, $34)$, quails $(3,31,34,38)$, partridges $(34,42,44)$, guinea fowl (40), pigeons (3), and peafowl (29).

In 1984 mycoplasmas were isolated from the turbinates of two mule (broiler) ducks in southwest France (15), and these mycoplasmas were identified as $M$. gallisepticum by immunofluorescence and growth inhibition (GI) tests. Later, the isolation of similar strains from geese in France was reported (11). Additional serological comparisons between these duck and goose isolates and some reference strains of $M$. gallisepticum in which GI and metabolism inhibition tests were used showed that the duck and goose strains were closely related to one another but were apparently less closely related to $M$. gallisepticum (16-18). Sodium dodecyl sulfatepolyacrylamide gel electrophoresis (SDS-PAGE) profiles of the proteins, the results of a restriction enzyme analysis of the DNAs, and estimates of the $G+C$ contents also suggested that the goose and duck strains were similar to one another but different from the reference strains of $M$. gallisepticum. Further support for these observations was provided by the results of Southern blot hybridization performed with rRNA and tuf gene probes $(16,45,46)$, in which the goose and duck strains again appeared to be similar to one another but fell into a cluster separate from $M$. gallisepticum. Finally, it was shown by DNA-DNA hybridization

\footnotetext{
${ }^{*}$ Corresponding author.
}

that there was a very close genetic relationship between the duck and goose strains but that the levels of homology of these strains with $M$. gallisepticum were only 40 to $46 \%$ (17, 18).

Johnson (26) has suggested that taxonomic groups of organisms can be based on DNA homology data, and according to his recommendations, the duck and goose strains should not be regarded as members of $M$. gallisepticum, but as members of a closely related species. This is because the levels of homology are well below the proposed minimum value of $60 \%$. The hypothesis that these strains should be placed in a separate species is strengthened by the proposal of an ad hoc committee of the International Committee on Systematic Bacteriology (41) that the phylogenetic definition of a species should be a taxon containing strains which exhibit approximately $70 \%$ or greater DNA-DNA relatedness.

Since strain $4229^{\mathrm{T}}$ ( $\mathrm{T}=$ type strain) is distinct from $M$. gallisepticum, it may represent a new mollicute species, and in this study we used the methods recommended by the International Committee on Systematic Bacteriology Subcommittee on the Taxonomy of Mollicutes (25) to establish this. In most investigations we included another strain (B2/85) which we isolated from a partridge in England in 1985 and which we also originally identified by immunofluorescence tests as $M$. gallisepticum. We included this strain because it had also been used in previous investigations performed with the gene probes $(45,46)$ and appeared to be more closely related to the duck and goose strains than to typical $M$. gallisepticum. 
TABLE 1. Results of serological tests performed with Mycoplasma sp. strains $4229^{\mathrm{T}}$ and $\mathrm{B} 2 / 85^{a}$

\begin{tabular}{|c|c|c|c|c|}
\hline \multirow{2}{*}{ Organism } & \multicolumn{2}{|c|}{ GI test results ${ }^{b}$} & \multicolumn{2}{|c|}{$\begin{array}{l}\text { Indirect immunofluorescence } \\
\text { test results }{ }^{c}\end{array}$} \\
\hline & $\begin{array}{l}\text { Reference } \\
\text { antiserum }\end{array}$ & $\begin{array}{l}\text { Reference } \\
\text { culture }\end{array}$ & $\begin{array}{l}\text { Reference } \\
\text { antiserum }\end{array}$ & $\begin{array}{l}\text { Reference } \\
\text { culture }\end{array}$ \\
\hline M. bovis Donetta ${ }^{\mathrm{T}}$ & $\mathrm{ND}^{d}$ & 0 & $\operatorname{gl}(\mathrm{gl})^{e}$ & ND \\
\hline Mycoplasma bovoculi M165/69 & ND & 0 & w gl(w gl) & ND \\
\hline M. cloacale $383^{\mathrm{T}}$ & 0 & 0 & $\mathrm{w} g \mathrm{l}(\mathrm{gl})$ & 0 \\
\hline Mycoplasma columbinum $\mathrm{MMP}^{\mathrm{T}}$ & 0 & 0 & 0 & gl \\
\hline M. dispar $462 / 2^{\mathrm{T}}$ & 0 & ND & ND & $\mathrm{gl}$ \\
\hline Mycoplasma faucium $\mathrm{DC} 333^{\mathrm{T}}$ & ND & 0 & ND & $\mathrm{gl}(\mathrm{gl})$ \\
\hline M. gallisepticum $\mathrm{PG} 31^{\mathrm{T}}$ & 0 & $1(2)$ & $1+(1+)$ & $1+(1+)$ \\
\hline Mycoplasma gallopavonis $\mathrm{WR}^{\mathrm{T}}$ & 0 & 0 & gl & 0 \\
\hline M. genitalium $\mathrm{G} 37^{\mathrm{T}}$ & 0 & ND & ND & s gl \\
\hline M. hyopneumoniae $\mathrm{J}^{\mathrm{T}}$ & 0 & ND & ND & $\mathrm{gl}(\mathrm{w} \mathrm{gl})$ \\
\hline M. hyosynoviae $\mathrm{S} 16^{\mathrm{T}}$ & 0 & ND & ND & $\mathrm{gl}(\mathrm{w} \mathrm{gl})$ \\
\hline M. lipofaciens $\mathrm{R} 171^{\mathrm{T}}$ & 0 & 0 & 0 & $\mathrm{gl}(\mathrm{gl})$ \\
\hline M. lipophilum $\mathrm{MaBy}^{\mathrm{T}}$ & ND & 0 & $\mathrm{gl}(\mathrm{gl})$ & ND \\
\hline M. muris RIII $4^{\mathrm{Tf}}$ & ND & 0 & $\mathrm{gl}(\mathrm{gl})$ & ND \\
\hline M. penetrans GTU-54-6A1 & 0 & ND & $\mathrm{gl}(\mathrm{gl})$ & ND \\
\hline M. pneumoniae $\mathrm{FH}^{\mathrm{T}}$ & ND & 0 & $\mathrm{gl}(\mathrm{gl})$ & ND \\
\hline Mycoplasma pulmonis $\mathrm{PG}^{\mathrm{T}}{ }^{\mathrm{T}}$ & ND & 0 & $\mathrm{gl}(\mathrm{gl})$ & ND \\
\hline Avian serovar J strain DJA & $1(1)$ & 0 & $\mathrm{gl}(\mathrm{gl})$ & 0 \\
\hline Avian serovar K strain DK-CPA & 0 & 0 & $\mathrm{gl}(\mathrm{gl})$ & 0 \\
\hline Avian serovar Q strain L3-10B & 0 & 0 & gl(w gl) & 0 \\
\hline Avian strain 700 & 0 & 0 & gl & 0 \\
\hline E. ellychniae ELCN-1 ${ }^{\mathrm{T}}$ & 0 & ND & ND & s gl \\
\hline
\end{tabular}

${ }^{a}$ Results were negative in comparisons with $M$. agalactiae $\mathrm{PG}^{\mathrm{T}}$, Mycoplasma alkalescens $\mathrm{D}^{2}{ }^{\mathrm{T}}$, Mycoplasma alvi $\mathrm{Ilsley}^{\mathrm{T}}$, Mycoplasma anatis $1340^{\mathrm{T}}$,

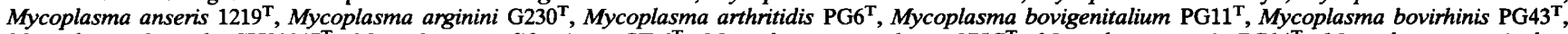
Mycoplasma buccale CH20247 $7^{\mathrm{T}}$, Mycoplasma californicum ST- $6^{\mathrm{T}}$, Mycoplasma canadense $275 \mathrm{C}^{\mathrm{T}}$, Mycoplasma canis $\mathrm{PG} 14^{\mathrm{T}}$, Mycoplasma capricolum California $\mathrm{Kid}^{\mathrm{T}}$, Mycoplasma caviae $\mathrm{G} 122^{\mathrm{T}}$, M. cavipharyngis $117 \mathrm{C}^{\mathrm{T}}$, Mycoplasma citelli $\mathrm{RG}-2 \mathrm{C}^{\mathrm{T}}$, M. collis $58 \mathrm{~B}^{\mathrm{T}}$, Mycoplasma columbinasale $694^{\mathrm{T}}$ Mycoplasma columborale MMP4 ${ }^{\mathrm{T}}$, Mycoplasma conjunctivae $\mathrm{HRC}^{2} \mathrm{1}^{\mathrm{T}}$, M. cricetuli $\mathrm{CH}^{\mathrm{T}}$, Mycoplasma cynos $\mathrm{H}^{2} 31^{\mathrm{T}}$, Mycoplasma edwardii $\mathrm{PG} 24^{\mathrm{T}}$, Mycoplasma equigenitalium $\mathrm{T} 37^{\mathrm{T}}$, Mycoplasma equirhinis $\mathrm{M} 432 / 72^{\mathrm{T}}, M$. fastidiosum $4822^{\mathrm{T}}, M$. felifaucium $\mathrm{PU}^{\mathrm{T}}, M$. feliminutum Ben ${ }^{\mathrm{T}}, M y c o p l a s m a$ felis $\mathrm{CO}^{\mathrm{T}}$, M. fermentans $\mathrm{PG}^{\mathrm{T}} \mathrm{T}$, M. flocculare Ms42 $2^{\mathrm{T}}$, Mycoplasma gallinaceum $\mathrm{DD}^{\mathrm{T}}$, M. gallinarum $\mathrm{PG}^{\mathrm{T}}{ }^{\mathrm{T}}$, Mycoplasma gateae $\mathrm{CS}^{\mathrm{T}}$, M. glycophilum $486^{\mathrm{T}}$, Mycoplasma hominis PG21 ${ }^{\mathrm{T}}$, M. hyopharyngis $\mathrm{H} 3-6 \mathrm{~B} \mathrm{~F}{ }^{\mathrm{T}}$, Mycoplasma hyorhinis $\mathrm{BTS}^{-} 7^{\mathrm{T}}$, M. indiense $3 \mathrm{~T}^{\mathrm{T}}$, Mycoplasma iners $\mathrm{PG} 30^{\mathrm{T}}$, M. iowae $695^{\mathrm{T}}$, Mesoplasma lactucae 831-C4 ${ }^{\mathrm{T}}, M$. leocaptivus $3 \mathrm{~L} 2^{\mathrm{T}}$, M. leopharyngis LL2 ${ }^{\mathrm{T}}$, Mycoplasma maculosum $\mathrm{PG} 15^{\mathrm{T}}$, Mycoplasma meleagridis $17529^{\mathrm{T}}$, Mycoplasma moatsii MK405 ${ }^{\mathrm{T}}, M$.

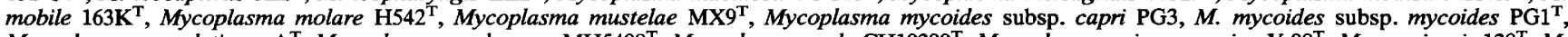
Mycoplasma neurolyticum A $\mathrm{A}^{\mathrm{T}}$, Mycoplasma opalescens $\mathrm{MH}^{2} 408^{\mathrm{T}}$, Mycoplasma orale $\mathrm{CH} 19299^{\mathrm{T}}$, Mycoplasma ovipneumoniae $\mathrm{Y}-98^{\mathrm{T}}, M$. axoniensis $128^{\mathrm{T}}, \mathrm{M}^{\mathrm{T}}$.

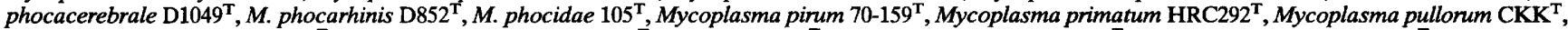
Mycoplasma putrefaciens $\mathrm{KS}-1^{\mathrm{T}}$, Mycoplasma salivarium $\mathrm{PG} 20^{\mathrm{T}}$, M. simbae $\mathrm{LX}^{\mathrm{T}}$, . spermatophilum $\mathrm{AH} 159^{\mathrm{T}}$, Mycoplasma spumans $\mathrm{PG} 13^{\mathrm{T}}$, Mycoplasma sualvi Mayfield $\mathrm{B}^{\mathrm{T}}$, Mycoplasma subdolum $\mathrm{TB}^{\mathrm{T}}$, Mycoplasma synoviae WVU $1853^{\mathrm{T}}$, M. testudinis $01008^{\mathrm{T}}$, Mycoplasma verecundum $107^{\mathrm{T}}$, avian serovar $\mathrm{N}$ strain FMN, avian serovar R strain DRA-O, bovine group 7 strain PG50, avian strains 1220, 1223, and 19756, E. lucivorax PIPN-2 ${ }^{\mathrm{T}}, E$. luminosum PIMN-1 ${ }^{\mathrm{T}}$, E. melaleucae $\mathrm{M1}^{\mathrm{T}}$, E. somnilux PYAN-1 ${ }^{\mathrm{T}}$, and Mesoplasma seiffertii $\mathrm{F}^{\mathrm{T}}{ }^{\mathrm{T}}$.

$b$ The values indicate the sizes of inhibition zones (in millimeters).

$c 0$, negative result; wk gl, weak glow; gl, glow; $\mathrm{s}$ gl, strong glow; $1+$, fluorescence. Reactions were considered positive only when fluorescence was observed.

${ }^{d}$ ND, not done.

- The data in parentheses are the results obtained with strain B2/85 or its antiserum. The other data are the results obtained with strain $4229^{\mathrm{T}}$ or its antiserum.

IFA tests performed with $M$. anseris, $M$. hyopharyngis, $M$. mobile, and $M$. pullorum also resulted in a glow with strain B2/85.

${ }_{f}^{f}$ Antiserum prepared with strain RIII8.

\section{MATERIALS AND METHODS}

Mycoplasma strains. The mycoplasma strains which we used are shown in Table 1 . Strain $4229^{\mathrm{T}}$ was isolated in southwest France from the turbinate of a mule duck (a Pekin-Barbary cross) with airsacculitis and pericarditis (15). Strain B2/85 was isolated from the eyes of a partridge in England; the bird was from a flock with sinusitis, and both infraorbital sinuses were very swollen, although mycoplasmas were not recovered from them.

Most reference strains were obtained from the former Food and Agriculture Organization-World Health Organization Collaborating Centre for Animal Mycoplasmas, University of Aarhus, Aarhus, Denmark, or from the same collection after it was transferred to the Mycoplasma Reference Facility at the National Collection of Type Cultures, London, England. The exceptions are indicated below. Mycoplasma genitalium, Mycoplasma fastidiosum, Mycoplasma hyopharyngis, Mycoplasma hyopneumoniae, Mycoplasma leocaptivus, Mycoplasma leopharyngis, Mycoplasma muris, Mycoplasma oxoniensis, Mycoplasma phocidae, Mycoplasma simbae, Mycoplasma spermatophilum, Entomoplasma ellychniae, Entomoplasma lucivorax, Entomoplasma luminosum, Entomoplasma melaleucae, Entomoplasma somnilux, Mesoplasma lactucae, and Mesoplasma seiffertii reference strains were supplied by J. G. Tully, Frederick Cancer Research Facility, Frederick, Md. Mycoplasma cavipharyngis, Mycoplasma cricetuli, Mycoplasma collis, Mycoplasma felifaucium, Mycoplasma indiense, and Mycoplasma testudinis reference strains were obtained from A. Hill, Medical Research Council Experimental Embryology and Teratology Unit, Carshalton, Surrey, United Kingdom. Mycoplasma phocarhinis and Mycoplasma phocacerebrale reference strains were supplied by $\mathrm{H}$. Kirchhoff, Institut für Mikrobiologie und Tierseuchen, Tierärztlichen Hochschule Hannover, Hannover, Germany. The Mycoplasma penetrans reference strain was supplied by S.-C. Lo, American Registry of Pathology, Department of Infectious and Parasitic Disease Pathology, Armed Forces Institute of 
Pathology, Washington, D.C. Mycoplasma lipofaciens, Mycoplasma glycophilum, and Mycoplasma cloacale reference strains were obtained from the collection of J. M. Bradbury. Avian strains 1220, 1223, and 19756 (members of three potential new species isolated from geese) and strain 700 (a member of a possible new species isolated from a chicken in Spain) were added to the collection of J. M. Bradbury by $Z$. Varga, Hungarian Academy of Science, Budapest.

Restriction enzyme analysis. In order to confirm that strains $4229^{\mathrm{T}}$ and $\mathrm{B} 2 / 85$ were genetically similar, restriction enzyme digests of the DNAs of these strains were compared. The DNA was extracted by a standard method (28), and the enzymes used were EcoRI, HindIII, and BglII.

Media, cultivation, purification, and tests for reversion. The media and conditions used to propagate most of the strains have been described previously (9). SP4 medium (39) was used for $M$. leocaptivus, $M$. muris, $M$. penetrans, $M$. simbae, $E$. lucivorax, $E$. luminosum, $E$. melaleucae, $E$. somnilux, and Mesoplasma lactucae. Horse serum medium (13) was used to culture Mycoplasma fermentans, Mycoplasma flocculare, Mycoplasma lipophilum, Mycoplasma mobile, and Mycoplasma pneumoniae. Attempts to grow E. ellychniae, $M$. fastidiosum, $M$. genitalium, M. hyopneumoniae, Mycoplasma hyosynoviae, $M$. oxoniensis, and $M$. leopharyngis were unsuccessful, and thus positive control cultures could not be included in the serological tests. Furthermore, Mycoplasma dispar, Mycoplasma feliminutum, and $M$. spermatophilum produced colonies that could be used in immunofluorescence tests, but we were unable to grow these organisms for GI tests.

Mycoplasma strains $4229^{\mathrm{T}}$ and $\mathrm{B} 2 / 85$ were subcultured routinely in broth or on agar (7) at $37^{\circ} \mathrm{C}$ in a carbon dioxide-rich $(5 \%, \mathrm{vol} / \mathrm{vol})$ atmosphere. They were purified by filter cloning them three times through filters with an average pore diameter of $450 \mathrm{~nm}$ (Nuclepore, Wallabs, Inc.). Tests for absence of reversion were carried out in broth without bacterial inhibitors. The culture of strain $4229^{\mathrm{T}}$ that was used for this experiment had been passaged seven times in our laboratory, but its passage history in France was not known. Strain B2/85 had undergone a total of seven passages in vitro. Ten passages of each strain were then made in broth without inhibitors, and each passage was examined for bacteria by subculturing it onto blood agar and by light microscopy.

Morphology and filtration studies. The colony morphology of strains $4229^{\mathrm{T}}$ and B2/85 was determined by light microscopy, and cell morphology was determined by light and electron microscopy $(9,12)$. Filterability studies were conducted by using 450- and 220-nm-pore-diameter membrane filters with starting cultures containing approximately $10^{7}$ $\mathrm{CFU} / \mathrm{ml}$. The numbers of colony-forming units per milliliter remaining after filtration through membranes having different pore sizes were determined.

Sterol requirement. The effect of cholesterol on the growth of strain $4229^{\mathrm{T}}$ was investigated after we first adapted the organism to grow in serum-free broth containing $1 \%$ bovine serum fraction (33).

Biochemical and biological properties. Strains $4229^{\mathrm{T}}$ and B2/85 were examined for their susceptibility to digitonin and sodium polyanetholsulfonate $(20,22)$. The other biochemical tests performed included direct and indirect tests for utilization of glucose $(1,19)$ and tests for hydrolysis of urea $(30$, 37 , hydrolysis of arginine, production of films and spots, phosphatase activity, tetrazolium reduction, liquefaction of coagulated horse serum (1), and hydrolysis of esculin and arbutin (23). Hemadsorption tests were conducted by using chicken, turkey, and duck erythrocytes, and hemagglutination activity was assessed by using chicken erythrocytes (24).

M. gallisepticum S6 was included in all of the tests described above as a positive or negative control culture, as appropriate, and in each test another reference species was selected as the other control. Thus, for example, in the test for hydrolysis of urea, Ureaplasma gallorale D6-1 was used as a positive control and $M$. gallisepticum was used as a negative control, while in the test for utilization of glucose, M. gallisepticum was the positive control and Mycoplasma gallinarum was the negative control.

Serological tests. Hyperimmune sera were prepared in rabbits against strains $4229^{\mathrm{T}}$ and $\mathrm{B} 2 / 85$ by using two rabbits for each strain. The method used was the method described previously (9), except that the initial numbers of intramuscular and subcutaneous inoculations were reduced from four to two and a booster intradermal inoculation containing $5 \mathrm{mg}$ of antigen protein in Freund's incomplete adjuvant was given at 21 days. Other antisera were supplied in conjunction with the reference strains indicated above, and additional sera against several of the species were supplied by J. G. Tully.

The serological tests used were the indirect fluorescent antibody (IFA) test (35) and the agar well modification of the GI test (6). The antisera prepared in rabbits against strains $4229^{\mathrm{T}}$ and $\mathrm{B} 2 / 85$ were titrated by the IFA test; these antisera were subsequently used undiluted in GI tests and diluted 1/40 in IFA tests. One serum against each strain was also selected for cross-testing with $M$. gallisepticum $\mathrm{PG} 31^{\mathrm{T}}$ and S6. A rabbit antiserum against $4229^{\mathrm{T}}$ prepared previously (18) was also included in these tests.

IFA and GI tests in which strains $4229^{\mathrm{T}}$ and $\mathrm{B} 2 / 85$ were compared with all of the previously described avian $M y c o$ plasma species and serovars were performed in two ways: by using cultures of strains $4229^{\mathrm{T}}$ and B2/85 and the avian reference sera and by using all of the reference cultures with antisera prepared against strains $4229^{\mathrm{T}}$ and B2/85. These tests included five additional serovars of Mycoplasma iowae, the three potential new species obtained from geese, and one species obtained from chickens.

To test strains $4229^{\mathrm{T}}$ and $\mathrm{B} 2 / 85$ with the previously recognized mammalian species, IFA tests were performed by using antisera against all of the mammalian reference strains. Positive controls were included except when we were not able or not permitted to grow the organism (e.g., Mycoplasma mycoides subsp. mycoides). For the GI tests cultures of the mammalian reference strains were tested with antisera against strains $4229^{\mathrm{T}}$ and B2/85 except for the species that we were not able to grow. For these species the reciprocal GI tests were performed by using reference antisera.

\section{RESULTS}

Restriction enzyme analysis. The DNA restriction patterns produced by strains $4229^{\mathrm{T}}$ and B2/85 were identical (Fig. 1) when all three enzymes were used, thus confirming the similarity of the two strains. These patterns were readily distinguishable from those of $M$. gallisepticum $\mathrm{PG} 31^{\mathrm{T}}$ and S6.

Growth characteristics. Strains $4229^{\mathrm{T}}$ and B2/85 grew well in conventional mycoplasma broth and on agar. Strain $4229^{\mathrm{T}}$ grew more rapidly than strain B2/85 in broth medium. There was no evidence of reversion to bacteria after passage in broth lacking bacterial inhibitors. 


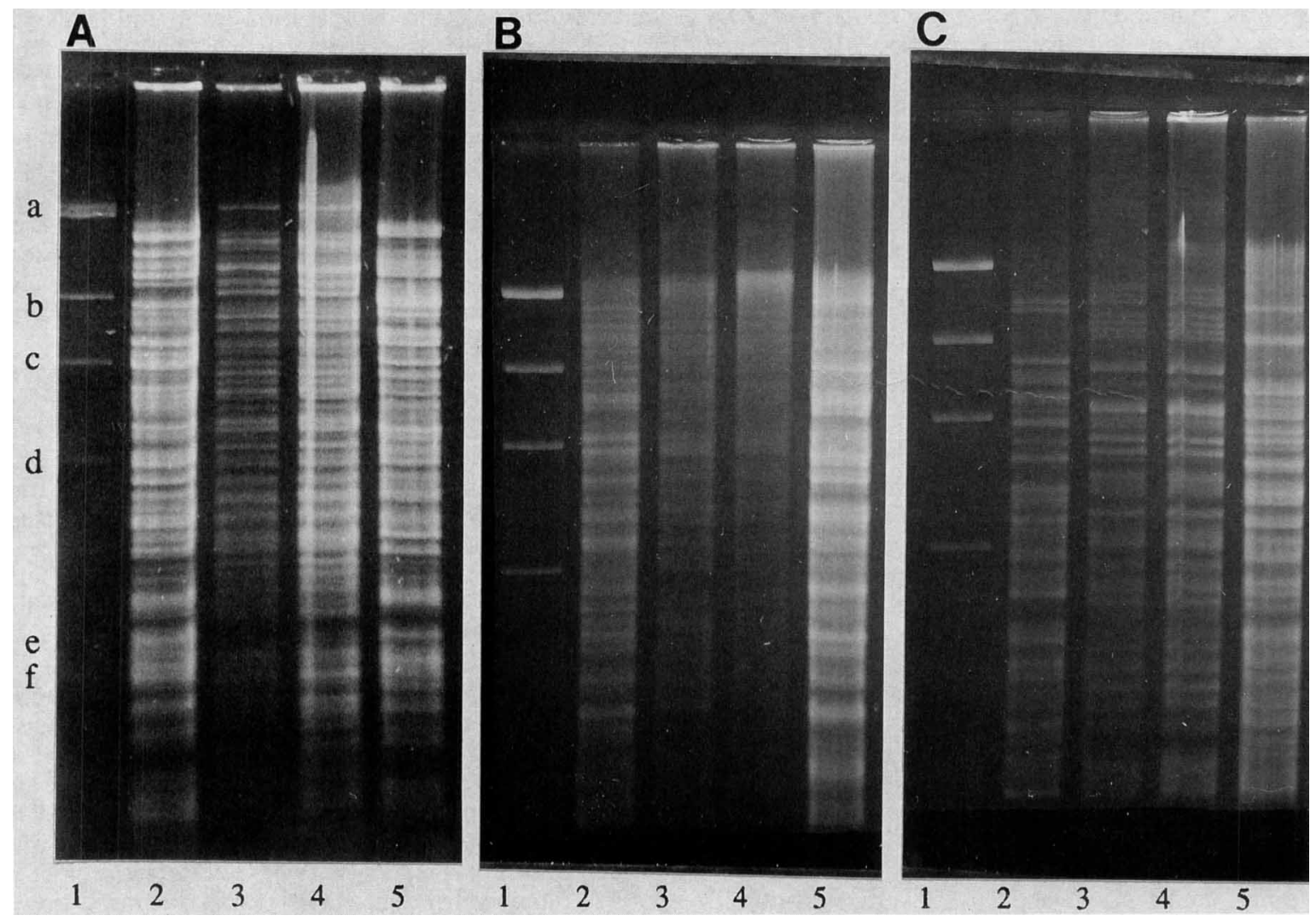

FIG. 1. Restriction endonuclease cleavage patterns of strains $4229^{\mathrm{T}}$ and $\mathrm{B} 2 / 85$ and $M$. gallisepticum PG31 ${ }^{\mathrm{T}}$ and S6 digested with EcoRI (A), HindIII (B), and BglII (C). Lanes 1, phage lambda HindIII digest; lanes 2, PG31 ${ }^{\mathrm{T}}$; lanes 3, 4229 ; lanes 4, B2/85; lanes 5, S6. The sizes of the phage lambda molecular weight markers were as follows: a, $23.1 \mathrm{kbp}$; b, $9.4 \mathrm{kbp}$; c, $6.7 \mathrm{kbp}$;, $4.4 \mathrm{kbp}$; e, $2.3 \mathrm{kbp}$;, $2.0 \mathrm{kbp}$.

Morphology and filtration studies. Colonies having typical "fried-egg" morphology were produced on agar by both strains. Giemsa-stained films revealed coccoid forms, and phase-contrast examination also revealed mainly coccoid elements, but there was some evidence of pleomorphism. Electron microscopy of ultrathin sections revealed a threelayer membrane but no evidence of a cell wall (Fig. 2). The organisms were mainly oval or flask shaped, and a tiplike structure was clearly visible in both strains.

Both strains exhibited a decrease in concentration of 2 $\log _{10} \mathrm{CFU} / \mathrm{ml}$ after passage through a 450 -nm-pore-diameter filter and a decrease in concentration of $3 \log _{10} \mathrm{CFU} / \mathrm{ml}$ after filtration through a 220 -nm-pore-diameter filter (Table 2).

Sterol requirement. As shown in Table 3, strain $4229^{\mathrm{T}}$ exhibited a positive growth response to increasing amounts of cholesterol (strain B2/85 was not included in these tests).

Biochemical and biological properties. Mycoplasma strains $4229^{\mathrm{T}}$ and B2/85 were susceptible to $1.5 \%$ (wt/vol) digitonin (widths of inhibition zones, 7 and $8 \mathrm{~mm}$, respectively). They were also susceptible to sodium polyanetholsulfonate, but the inhibition zones were 2 to $3 \mathrm{~mm}$ smaller than the zones observed with digitonin. The organisms utilized glucose but gave negative results for hydrolysis of arginine and urea, production of films and spots, phosphatase activity, liquefaction of coagulated horse serum, and hydrolysis of esculin and arbutin. The mycoplasmas reduced tetrazolium both aerobically and anaerobically, but the reactions were weak. There was strong hemadsorption of chicken, turkey, and duck erythrocytes to colonies of strains $4229^{\mathrm{T}}$ and $\mathrm{B} 2 / 85$, with approximately 75 to $100 \%$ of the individual colony surfaces covered. The $M$. gallisepticum control behaved similarly. In the hemagglutination test strains $4229^{\mathrm{T}}$ and B2/85 and $M$. gallisepticum S6 gave reciprocal titers of 32, 16 , and 32 , respectively.

Serological tests. Rabbit antisera prepared against strains $4229^{\mathrm{T}}$ and B2/85 gave inhibition zones that were 5 to $7 \mathrm{~mm}$ wide in GI tests and reciprocal titers of 1,280 to 2,560 in IFA tests when they were tested with the homologous culture and with each other. IFA titers were considerably less when two strains of $M$. gallisepticum were used (Table 4).

The serological tests performed with antiserum to strain $4229^{\mathrm{T}}$ and the heterologous avian Mycoplasma species and serovars gave negative results in GI and IFA tests except for the reactions shown in Table 1 . The only results that were interpreted as positive were the immunofluorescence reactions with the type strain of $M$. gallisepticum. A similar reaction was observed in the reciprocal tests in which reference antiserum against $M$. gallisepticum was used, and a slight one-way reaction was observed in the GI test when the $M$. gallisepticum culture was used. The results obtained with strain B2/85 and its antiserum were virtually the same as the results obtained with $4229^{\mathrm{T}}$.

\section{DISCUSSION}

At the outset of this study a restriction enzyme analysis in which three different enzymes were used demonstrated that strains $4229^{\mathrm{T}}$ and $\mathrm{B} 2 / 85$ were indistinguishable but were 


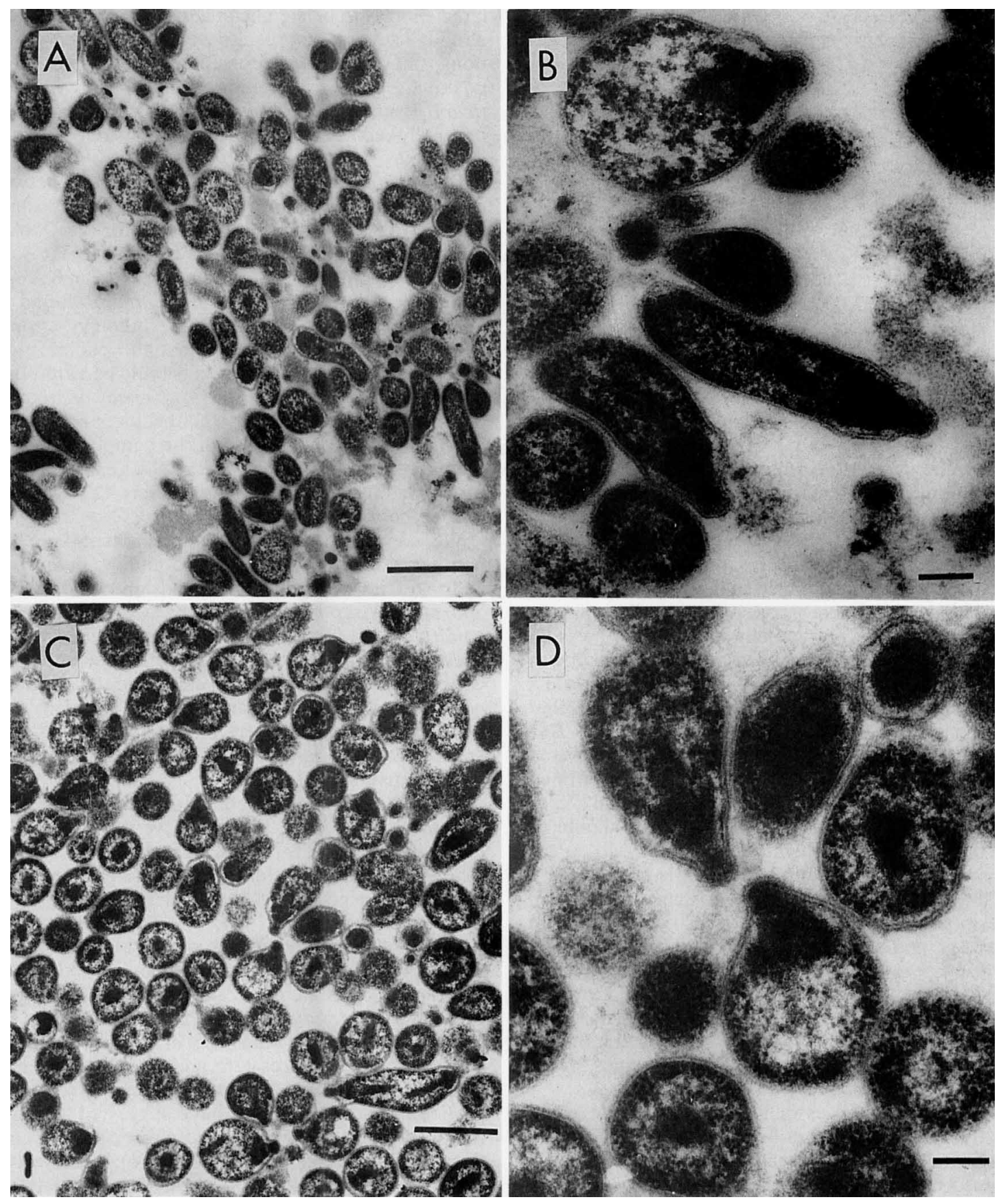

FIG. 2. Electron micrographs of thin sections of $M$. imitans after $48 \mathrm{~h}$ in broth culture. (A and C) Strains $4229^{\mathrm{T}}$ and B2/85, respectively, showing round, elongated, and flask-shaped organisms. Bar $=1,000 \mathrm{~nm}$. (B and D) Higher magnification of panels A and C, respectively, showing the three-layer membrane and terminal tip structure. Bar $=200 \mathrm{~nm}$.

clearly different from two strains of $M$. gallisepticum. Previous studies $(17,18)$ had revealed differences in DNA restriction enzyme profiles between strain $4229^{\mathrm{T}}$ and reference strains of $M$. gallisepticum, but strain B2/85 had not been included in those comparisons.

The three enzymes were selected because they gave a large number of cuts in the DNA and might therefore be expected to reveal minor differences between strains. It could therefore be assumed that strains $4229^{\mathrm{T}}$ and $\mathrm{B} 2 / 85$ were closely related. This observation also substantiates the
TABLE 2. Viability of strains $4229^{\mathrm{T}}$ and $\mathrm{B} 2 / 85$ before and after filtration

\begin{tabular}{lccc}
\hline Strain & \multicolumn{3}{c}{ CFU/ml } \\
\cline { 2 - 4 } & $\begin{array}{c}\text { Before } \\
\text { filtration }\end{array}$ & $\begin{array}{c}\text { After filtration with } \\
\text { 450-nm-pore-diam- } \\
\text { eter filters }\end{array}$ & $\begin{array}{c}\text { After filtration with } \\
\text { 220-nm-pore-diam- } \\
\text { eter filters }\end{array}$ \\
\hline $4229^{\mathrm{T}}$ & $7.2 \times 10^{6}$ & $4.0 \times 10^{4}$ & $1.6 \times 10^{3}$ \\
$\mathrm{~B} 2 / 85$ & $6.7 \times 10^{6}$ & $9.9 \times 10^{4}$ & $3.6 \times 10^{3}$ \\
\hline
\end{tabular}


TABLE 3. Growth response of strain $4229^{\mathrm{T}}$ to cholesterol

\begin{tabular}{lcc}
\hline $\begin{array}{c}\text { Supplement(s) added to } \\
\text { serum-free basal medium }\end{array}$ & $\begin{array}{c}\text { Cholesterol concn } \\
(\mu \mathrm{g} / \mathrm{ml}) \text { in } \\
\text { medium }\end{array}$ & $\begin{array}{c}\text { Protein yield } \\
(\mathrm{mg} / 100 \mathrm{ml})\end{array}$ \\
\hline Bovine serum fraction (control) & 0 & 1.95 \\
None & 0 & 0.15 \\
Bovine serum albumin & 0 & 0.48 \\
Bovine serum albumin, Tween & 0 & 0.43 \\
80, and palmitic acid & 1 & 0.81 \\
& 5 & 1.08 \\
& 10 & 1.20 \\
\end{tabular}

data of Yogev et al. $(45,46)$ who examined these two strains with the pMC5 rRNA probe and the tuf gene probe and found that they produced similar genomic fingerprints.

Strains $4229^{\mathrm{T}}$ and B2/85 had properties consistent with membership in the class Mollicutes as defined by the International Committee on Systematic Bacteriology Subcommittee on the Taxonomy of Mollicutes (25). Thus, the colonies resembled fried eggs, and the cells were pleomorphic. There was no evidence of helical or motile forms and therefore no evidence that the organism belonged to the family Spiroplasmataceae. An electron microscope examination of thin sections revealed a three-layer membrane, and there was no evidence of a cell wall. The morphology of the organism was very similar to that of $M$. gallisepticum in that it possessed a tiplike structure. In other studies (36) we have shown that this structure has an attachment function.

The sterol requirement of strain $4229^{\mathrm{T}}$ was demonstrated by its growth response to cholesterol and was confirmed indirectly by the susceptibility of strains $4229^{\mathrm{T}}$ and B2/85 to digitonin. We therefore propose that this organism should be assigned to the family Mycoplasmataceae.

Since strain $4229^{\mathrm{T}}$ did not utilize urea, it is considered a member of the genus Mycoplasma rather than a member of the genus Ureaplasma, and the remaining biochemical and serological tests were carried out to provide a species description.

The G+C content of the DNA of strain $4229^{\mathrm{T}}$ has been estimated previously to be $31.9 \mathrm{~mol} \%(17,18)$; this value falls within the normal range of values for members of the Mollicutes but is lower by 1 to $2 \mathrm{~mol} \%$ than the values for $M$. gallisepticum.

There was no serological evidence to suggest a relationship with any previously described Mycoplasma species other than the relationship already established with $M$. gallisepticum. Of the 107 mammalian and avian species, serovars, and strains compared by using GI tests with strains $4229^{\mathrm{T}}$ and B2/85, only $M$. gallisepticum and avian serovar J showed any sort of reaction, but zones were not considered

TABLE 4. Cross-testing of strains $4229^{\mathrm{T}}$ and $\mathrm{B} 2 / 85$ and $M$. gallisepticum strains by immunofluorescence

\begin{tabular}{lrrrr}
\hline \multirow{2}{*}{ Strain } & \multicolumn{4}{c}{ Reciprocal titers with the following antisera: } \\
\cline { 2 - 5 } & $4229^{\mathrm{T} a}$ & $4229^{\mathrm{T}}$ & \multicolumn{1}{c}{ B2/85 } & PG31 $^{\mathrm{T}}$ \\
\hline $4229^{\mathrm{T}}$ & 640 & 1,280 & 2,560 & 320 \\
B2/85 & 640 & 1,280 & 1,280 & 160 \\
PG31 & 20 & 40 & 40 & $>1,280$ \\
S6LP & 40 & 320 & 320 & $>1,280$ \\
\hline
\end{tabular}

${ }^{a}$ This antiserum had been prepared for a previous study (18). large enough to be significant. In immunofluorescence tests, although several test results were recorded as glowing reactions, they were not considered positive, and the only positive reactions were the reactions seen with $M$. gallisepticum. Even these reactions were not as strong as had been originally recorded when the isolates were first (erroneously) identified.

Despite the many phenotypic similarities between strain $4229^{\mathrm{T}}$ and $M$. gallisepticum, the SDS-PAGE protein profiles and restriction enzyme analysis data for the DNAs of these organisms revealed obvious differences (18). It is interesting that Dovč et al. (14), who developed a polymerase chain reaction for detection of $M$. gallisepticum, found that strain $4229^{\mathrm{T}}$ also gave a specific signal, although a commercially produced kit did not (8a). Thus, the choice of the DNA sequence used for amplification should be carefully assessed if distinction between these organisms is required. This finding is also supported by the results of another study (21) in which an oligonucleotide probe complementary to one of the variable regions in the $16 \mathrm{~S}$ rRNA gene was used and the probe was found to react with strains $4229^{\mathrm{T}}$ and $\mathrm{B} 2 / 85$ and one of the goose strains.

We concluded that, despite the phenotypic similarities between strains $4229^{\mathrm{T}}$ and $\mathrm{B} 2 / 85$ and $M$. gallisepticum, the 40 to $46 \%$ level of genetic relationship between strain $4229^{\mathrm{T}}$ and $M$. gallisepticum shown by DNA-DNA hybridization studies cannot justify assigning these organisms to the same species (26). This situation is reminiscent of the situation which existed with Mycoplasma agalactiae and Mycoplasma bovis. These organisms were originally assigned to the same species but were finally accepted as two distinct species on the basis of DNA-DNA hybridization values (approximately 40\%) (2).

From these results we conclude that strain $4229^{\mathrm{T}}$ is a new Mycoplasma species, for which we propose the name $M y$ coplasma imitans. Strain B2/85, which was isolated from a different avian species and in a different country than strain $4229^{\mathrm{T}}$, produced almost identical results in every test that was performed.

It is important to determine whether this new Mycoplasma species represents a threat to the poultry industry, either as a pathogen or as a complicating factor in serological testing programs for $M$. gallisepticum. Strains $4229^{\mathrm{T}}$ and B2/85 have been shown to cause ciliostasis in chicken and duck embryo tracheal organ cultures (36) and mortality of embryonated chicken, goose, and duck eggs $(10,16,36)$. The results of preliminary in vivo studies have suggested that strain $4229^{\mathrm{T}}$ may cause reduced growth and airsacculitis in goslings and decreased liver size in older birds (10). Commercial turkeys experimentally infected by intranasal inoculation of strain $4229^{\mathrm{T}}$ when they were 2 days old showed sinusitis, coryza, conjunctivitis, and airsacculitis when they were autopsied after 22 days (16). Mycoplasma-free turkeys infected with strain B2/85 by using eye drops and by inoculation into the thoracic airsac when they were 1 day old showed only transient mild respiratory signs (35a), but there was seroconversion and spread to contact birds. No clinical signs or lesions were observed in 8-week-old specific-pathogen-free chickens inoculated intratracheally with either strain $4229^{\mathrm{T}}$ or strain B2/85 or with one of the goose strains (43), but it is possible that the birds had developed natural resistance by this age. It is also possible that, like some strains of $M$. gallisepticum, the full pathogenic potential of the organisms may be realized only in the presence of other agents (8).

Description of Mycoplasma imitans sp. nov. Mycoplasma imitans (im'i.tans. L. v. gerund imitans, imitating, mimick- 
ing, referring to the organism's phenotypic resemblance to M. gallisepticum). Thin sections reveal oval and flaskshaped cells with a three-layer membrane and no outer wall. An attachment organelle is present.

Cells pass through 450 -nm-pore-size filters and through 220-nm-pore-size filters with some loss.

Typical "fried-egg" colonies are formed.

The organism is resistant to penicillin and thallium acetate, and there is no reversion to bacterial forms in the absence of these compounds.

Cultures show a growth response to cholesterol, and growth is inhibited by digitonin.

Glucose is utilized, but arginine and urea are not utilized.

Triphenyl tetrazolium chloride is reduced aerobically and anaerobically.

There is no production of films and spots or phosphatase activity, no liquefaction of coagulated horse serum, and no hydrolysis of esculin or arbutin.

There is hemadsorption by chicken, turkey, and duck erythrocytes and hemagglutination of chicken erythrocytes.

The species is serologically distinct from other Mycoplasma species except $M$. gallisepticum, to which it is genetically related at a level of approximately 40 to $46 \%$ (17, 18).

The type strain was isolated from the turbinate of a duck with respiratory disease.

The pathogenicity of this organism is not fully known, but there is evidence of ciliostasis in avian tracheal organ cultures and of embryo mortality.

The $\mathrm{G}+\mathrm{C}$ content of the DNA is $31.9 \mathrm{~mol} \%(17,18)$.

The type strain is strain $4229(=$ NCTC $11733=$ ATCC 51306).

\section{ACKNOWLEDGMENTS}

We thank P. Carle and A. McBain for valuable assistance and G. Ross for preparation of the electron micrographs. We also thank E. A. Freundt, A. Hill, H. Kirchhoff, R. H. Leach, S.-C. Lo, and J. G. Tully for kindly providing cultures and antisera.

\section{REFERENCES}

1. Aluotto, B. B., R. G. Wittler, C. O. Williams, and J. E. Faber. 1970. Standardized bacteriologic techniques for the characterization of Mycoplasma species. Int. J. Syst. Bacteriol. 20:35-58.

2. Askaa, G., and H. Ernø. 1976. Elevation of Mycoplasma agalactiae subsp. bovis to species rank: Mycoplasma bovis (Hale et al.) comb. nov. Int. J. Syst. Bacteriol. 26:322-325.

3. Benčina, D., D. Dorrer, and T. Tadina. 1987. Mycoplasma species isolated from six avian species. Avian Pathol. 16:653664.

4. Benčina, D., T. Tadina, and D. Dorrer. 1988. Natural infection of ducks with Mycoplasma synoviae and Mycoplasma gallisepticum and Mycoplasma egg transmission. Avian Pathol. 17:441449.

5. Benčina, D., T. Tadina, and D. Dorrer. 1988. Natural infection of geese with Mycoplasma gallisepticum and Mycoplasma synoviae and egg transmission of the mycoplasmas. Avian Pathol. 17:925-928.

6. Black, F. T. 1973. Modification of the growth inhibition test and its application to human T-mycoplasmas. Appl. Microbiol. 25:528-533.

7. Bradbury, J. M. 1977. Rapid biochemical tests for characterization of the Mycoplasmatales. J. Clin. Microbiol. 5:531-534.

8. Bradbury, J. M. 1984. Avian mycoplasma infections: prototype of mixed infections with mycoplasmas, bacteria and viruses. Ann. Microbiol. (Inst. Pasteur) 135A:83-89.

8a.Bradbury, J. M. Unpublished data.

9. Bradbury, J. M., M. Forrest, and A. Williams. 1983. Mycoplasma lipofaciens, a new species of avian origin. Int. J. Syst. Bacteriol. 33:329-335.
10. Buntz, B. 1987. Isolement et mise en évidence du pouvoir pathogene de $M$. gallisepticum chez l'oie (Anser anser). Ph.D. thesis. Université de Bordeaux II, Villenave d'Ornon, France.

11. Buntz, B., J. M. Bradbury, A. Vuillaume, and D. RousselotPaillet. 1986. Isolation of Mycoplasma gallisepticum from geese. Avian Pathol. 15:615-617.

12. Cole, R. M. 1983. Transmission electron microscopy: basic techniques. Methods Mycoplasmol. 1:43-50.

13. Costas, M., R. H. Leach, and D. L. Mitchelmore. 1987. Numerical analysis of PAGE protein patterns and the taxonomic relationships within the "Mycoplasma mycoides cluster." J. Gen. Microbiol. 133:3319-3329.

14. Dovč, P., D. Benčina, R. Antes, and W. Mann. 1992. Recombinant DNA probes and PCR for detection of Mycoplasma gallisepticum strains. Int. Org. Mycoplasmol. Lett. 2:109.

15. Dupiellet, J.-P. 1984. Mycoplasmes et acholeplasmes des palmipedes a foie gras: isolement, caractérisation, étude du rôle dans la pathologie. Rapport de D.E.A. de Pathologie, Université de Bordeaux II, Villenave d'Ornon, France.

16. Dupiellet, J.-P. 1988. Mycoplasmes de l'oie et du canard: contribution a l'etude serologique et moléculaire de souches aparentées a Mycoplasma gallisepticum. Ph.D. thesis. Université de Bordeaux II, Villenave d'Ornon, France.

17. Dupiellet, J.-P., A. Vuillaume, D. Rousselot, J. M. Bové, and J. M. Bradbury. 1988. Serological and molecular studies on Mycoplasma gallisepticum strains, p. 150. Abstr. 7th Congr. Int. Org. Mycoplasmol. International Organization for Mycoplasmology.

18. Dupiellet, J. P., A. Vuillaume, D. Rousselot, J. M. Bové, and J. M. Bradbury. 1990. Serological and molecular studies on Mycoplasma gallisepticum strains. Zentralbl. Bakteriol. Suppl. 20:859-864.

19. Edward, D. G. ff., and W. B. Moore. 1975. A method for determining utilization of glucose by mycoplasmas. J. Med. Microbiol. 8:451-454.

20. Ernø, H., and L. Stipkovits. 1973. Bovine mycoplasmas. Cultural and biochemical studies. I. Acta Vet. Scand. 19:436-449.

21. Fernandez, C., J. G. Mattsson, G. Bölske, S. Levisohn, and K.-E. Johansson. Species-specific oligonucleotide probes complementary to 16S rRNA of Mycoplasma gallisepticum and Mycoplasma synoviae. Res. Vet. Sci., in press.

22. Freundt, E. A., B. E. Andrews, H. Ernø, M. Kunze, and F. T. Black. 1973. The sensitivity of Mycoplasmatales to sodium polyanetholsulfonate and digitonin. Zentralbl. Bakteriol. Parasitenkd. Infektionskr. Hyg. Abt. 1 Orig. Reihe A 255:104-112.

23. Freundt, E. A., H. Ernø, and R. M. Lemcke. 1979. Identification of mycoplasmas. Methods Microbiol. 13:377-434.

24. Gardella, R. S., and R. A. DelGiudice. 1983. Hemagglutination, hemadsorption and hemolysis. Methods Mycoplasmol. 1:379384.

25. International Committee on Systematic Bacteriology Subcommittee on the Taxonomy of Mollicutes. 1979. Proposal of minimal standards for descriptions of new species of the class Mollicutes. Int. J. Syst. Bacteriol. 29:172-180.

26. Johnson, J. L. 1984. Bacterial classification. III. Nucleic acids in bacterial classification, p. 8-11. In N. R. Krieg and J. G. Holt (ed.), Bergey's manual of systematic bacteriology, vol. 1. Williams and Wilkins, Baltimore.

27. Jordan, F. T. W., and M. M. Amin. 1980. A survey of mycoplasma infections in domestic poultry. Res. Vet. Sci. 28:96-100.

28. Kleven, S. H., G. F. Browning, D. M. Bulach, E. Ghiocas, C. J. Morrow, and K. G. Whithear. 1988. Examination of Mycoplasma gallisepticum strains using restriction endonuclease DNA analysis and DNA-DNA hybridization. Avian Pathol. 17:559-570.

29. Kleven, S. H., C. J. Morrow, and K. G. Whithear. 1988. Comparison of Mycoplasma gallisepticum strains by hemagglutination-inhibition and restriction enzyme analysis. Avian Dis. 32:731-741

30. Livingston, C. W. 1972 . Isolation of T-strain mycoplasma from Texas feedlot cattle. Am. J. Vet. Res. 33:1925-1929.

31. Madden, D. L., W. H. Henderson, and H. E. Moses. 1967. Case report: isolation of Mycoplasma gallisepticum from bobwhite 
quail (Colinus vinginianus). Avian Dis. 11:378-380.

32. Osborn, O. H., and B. S. Pomeroy. 1958. Isolation of the agent of infectious sinusitis of turkeys from naturally infected pheasants. Avian Dis. 2:370-372.

33. Razin, S., and J. G. Tully. 1970. Cholesterol requirement of mycoplasmas. J. Bacteriol. 102:306-310.

34. Reece, R. L., L. Ireland, and D. A. Barr. 1986. Infectious sinusitis associated with Mycoplasma gallisepticum in gamebirds. Aust. Vet. J. 63:167-168.

35. Rosendal, S., and F. T. Black. 1972. Direct and indirect immunofluorescence of unfixed and fixed mycoplasma colonies. Acta Pathol. Microbiol. Scand. Sect. B 80:615-622.

35a.Saed, O. M., and J. M. Bradbury. Unpublished data.

36. Saed, O. M., G. Ross, and J. M. Bradbury. 1990. Pathogenicity studies on an avian mycoplasma related to Mycoplasma gallisepticum. Int. Org. Mycoplasmol. Lett. 1:547-548.

37. Shepard, M. C., and D. R. Howard. 1970. Identification of "T" mycoplasmas in primary agar cultures by means of a direct test for urease. Ann. N.Y. Acad. Sci. 174:809-819.

38. Tiong, S. K. 1978. Isolation of Mycoplasma gallisepticum from sinuses of three quail (Corturnix cortunix japonica). Vet. Rec. 103:539.

39. Tully, J. G., R. G. Whitcomb, H. F. Clark, and D. L. Williamson. 1977. Pathogenic mycoplasmas: cultivation and vertebrate pathogenicity of a new spiroplasma. Science 195:892-894.
40. Van Roekel, H., and O. M. Olesiuk. 1953. The etiology of chronic respiratory disease, p. 289-303. In Proceedings of the 90th Annual Meeting of the American Veterinary Medicine Association. American Veterinary Medical Association, Chicago.

41. Wayne, L. G., D. J. Brenner, R. R. Colwell, P. A. D. Grimont, O. Kandler, M. I. Krichevsky, L. H. Moore, W. E. C. Moore, R. G. E. Murray, E. Stackebrandt, M. P. Starr, and H. G. Trüper. 1987. Report of the Ad Hoc Committee on Reconciliation of Approaches to Bacterial Systematics. Int. J. Syst. Bacteriol. 37:463-464.

42. Wichmann, R. W. 1957. Case report-PPLO infection in chukar partridges (Alectoris graeca). Avian Dis. 1:222-226.

43. Yagihashi, T., T. Nunoya, and M. Tajima. 1988. Pathogenicity for chickens of six strains of Mycoplasma gallisepticum isolated from various birds. Avian Pathol. 17:725-729.

44. Yoder, H. W., Jr., and M. S. Hofstad. 1964. Characterisation of avian mycoplasmas. Avian Dis. 8:481-512.

45. Yogev, D., S. Levisohn, S. H. Kleven, D. Halachmi, and S. Razin. 1988. Ribosomal RNA gene probes to detect intraspecies heterogeneity in Mycoplasma gallisepticum and M. synoviae. Avian Dis. 32:220-231.

46. Yogev, D., S. Sela, H. Bercovier, and S. Razin. 1988. Elongation factor (EF-Tu) gene probe detects polymorphism in Mycoplasma strains. FEMS Microbiol. Lett. 50:145-149. 